\title{
AGRONOMIC AND PRODUCTIVE CHARACTERISTICS OF SUNFLOWER INTERCROPPED WITH FORAGE IN A CROP-LIVESTOCK INTEGRATION SYSTEM $^{1}$
}

\author{
JAMILE MARIA DA SILVA DOS SANTOS ${ }^{2} *$, CLOVIS PEREIRA PEIXOTO ${ }^{2}$, MARCOS ROBERTO DA SILVA $^{2}$, \\ ADEMIR TRINDADE ALMEIDA², ANA MARIA PEREIRA BISPO DE CASTRO
}

\begin{abstract}
The objective of this study was to evaluate the agronomic characteristics and yield of a sunflower crop grown together with forages in a crop-livestock integration system. The experiment was carried out in a randomized complete block design, in a $3 \times 3+1$ factorial scheme. Three sunflower intercropping with forage plants [sunflower + Urochloa ruziziensis (SB); sunflower + Panicum maximum cv. Tanzania (SP); sunflower + Urochloa ruziziensis + Cajanus cajan $(\mathrm{SBGu})$ ], sown in three ways [simultaneous sowing (SS), delayed sowing (DS), and simultaneous sowing with herbicide/graminicide (SSH) application], with the monocroped sunflower as a control, with three years of cultivation (2013, 2014, and 2015). The following characteristics were evaluated: plant height, stalk diameter, head diameter, number of achenes per heads, the mass of thousand achenes, harvest index, and the productivity of achenes. Data were submitted to analysis of variance, and the means were compared by the Tukey and Dunnett tests at 5\% probability. The SB and SBGu intercropped promote greater sunflower productivity. The forage Panicum maximum cv. Tanzania in intercropped with sunflower reduces plant production components and productivity. Lapsed sowing delayed and simultaneous sowing with herbicide/graminicide application promote higher productivity of sunflower.
\end{abstract}

Keywords: Helianthus annuus L. Intercropping. Forage plants. Grass.

\section{CARACTERÍSTICAS AGRONÔMICAS E PRODUTIVAS DE GIRASSOL CONSORCIADO COM FORRAGEIRAS NO SISTEMA INTEGRAÇÃO LAVOURA-PECUÁRIA}

\begin{abstract}
RESUMO - Objetivou-se avaliar as características agronômicas e a produtividade do girassol cultivado em consórcio com forrageiras no sistema integração lavoura-pecuária. $\mathrm{O}$ delineamento utilizado foi blocos casualizados, em esquema fatorial $3 \times 3+1$. Assim, foram estudados, três consórcios do girassol com plantas forrageiras (girassol + Urochloa ruziziensis (GB), girassol + Panicum maximum cv. Tanzânia (GP), girassol + Urochloa ruziziensis + Cajanus cajan $(\mathrm{GBGu})$ ), semeados de três formas diferentes (semeadura simultânea (SS), semeadura defasada (SD) e semeadura simultânea com aplicação de herbicida/graminicida (SSH)), tendo o girassol solteiro como testemunha, com quatro repetições, em três anos de cultivo (2013, 2014 e 2015). Foram avaliadas as características: altura de planta, diâmetro da haste, diâmetro do capítulo, número de aquênios por capítulo, massa de mil aquênios, índice de colheita e a produtividade de aquênios. Os dados foram submetidos à análise de variância e as médias comparadas pelos testes Tukey e Dunnett, a 5\% de probabilidade. Os consórcios GB e GBGu promovem maior produtividade do girassol. A forrageira Panicum maximum cv. Tanzânia em consórcio com o girassol reduz os componentes de produção da planta e a produtividade. A semeadura defasada e a simultânea com aplicação de herbicida/graminicida promovem maior produtividade do girassol.
\end{abstract}

Palavras-chave: Helianthus annuus L. Consorciação. Forrageiras. Gramíneas.

\footnotetext{
${ }^{*}$ Corresponding author

${ }^{1}$ Received for publication in $05 / 10 / 2017$; accepted in $01 / 30 / 2019$.

Paper extracted from the doctoral thesis of the first author.

${ }^{2}$ Center for Agricultural, Environmental and Biological Sciences, Universidade Federal do Recôncavo da Bahia, Cruz das Almas, BA, Brazil; jmariasantos7@gmail.com - ORCID: 0000-0002-7509-3147, cppeixot@gmail.com - ORCID: 0000-0002-6618-1700, mrsilva@ufrb.edu.br - ORCID: 0000-0001-5808-9130, ademirtrindadeufrb@hotmail.com - ORCID: 0000-0001-5233-7607, anamariapbs@hotmail.com - ORCID: 0000-0001-8898-2624.
} 


\section{INTRODUCTION}

Sunflower (Helianthus annuus L.) is a versatile oleaginous plant that develops well on most arable soils and, because of its wide adaptability, can be grown in different brazilian regions. Its cultivation is predominant in the states of Mato Grosso, Goiás, Minas Gerais, Mato Grosso do Sul, and the Rio Grande do Sul. However, research has shown that sunflower can be successfully cultivated in other regions, such as in the Northeast region (CONAB, 2017; OLIVEIRA et al., 2010).

The estimated national sunflower productivity is $1479 \mathrm{~kg} \mathrm{ha}^{-1}$, with prospects for an increased cultivated area in 2017 (CONAB, 2017). This expansion is due to the viability of cultivation and the varied use of its products and by-products (edible oil, confectionery, bird feed, animal feed, ornamentation, and oil for biofuel). Also, sunflower crop can be used in crop-livestock integration systems based on rotation, succession or crop consortium approaches (CASTRO et al., 1996; BRIGHENTI et al., 2008).

The intercropped is a modality of croplivestock integration (CLI) and aims to associate two or more crops in the same area, always aiming at the increased production, higher quality of food, enrichment of the biological life of the soil, and reduced soil degradation (CRUSCIOL et al., 2009; CECCON et al., 2010).

In soil conservation, these intercroppeds or arrangements are usually established in a no-tillage system (NTS), which benefits the soil-plantatmosphere system (e.g., by improving soil quality and crop yields) (LOSS et al., 2011; NASCENTE; LI; CRUSCIOL, 2015).

In this paper, to be successful in the implementation of the consortium system in which grain production is targeted, the most important factors that should be taken into account are the choice of the forage plant and the season of the consortium (PARIZ et al., 2011).

The introduction of leguminous forage species and grasses in the CLI system, provided they are compatible with grain culture, is beneficial to production systems, with increased biomass production, biological nitrogen fixation, and feed quality for animal feed (SCHUNKE, 2001; TIRITAN et al., 2013).

The use of perennial forage species in this system, as in the case of grasses, would have a dual purpose: pasture production to serve as food in the cattle ranch or as a plant to produce straw, due to its high $\mathrm{C} / \mathrm{N}$ ratio, slow decomposition, and vigorous, deep root system with tolerance to water deficit. The legume can also be included in the CLI system as an alternative to producing high-quality fodder, besides bringing other benefits, mainly related to the soil being nitrogen source by the biological nitrogen fixation process $(\mathrm{BNF})$ and low $\mathrm{C} / \mathrm{N}$ ratio (SILVA et al., 2006; CRUSCIOL et al., 2009; OLIVEIRA et al., 2011; SHEAHAN, 2012).

The productivity of sunflower achenes is considered a complex feature that results from the association of multiple components and some agronomic characteristics that undergo management influence and climatic conditions (AMORIM et al., 2008). In evaluating the sunflower culture within the CLI system, there are positive and negative responses regarding the interference of the intercropping species in their productivity (RODRIGUES et al., 2014; GOMES; CHAVES; GUERRA, 2015).

Given the above, the objective was to study the agronomic and productive characteristics of sunflower cultivated intercropped with forages in the crop-livestock integration system.

\section{MATERIAL AND METHODS}

The study was developed at the Experimental Farm of the Center for Agricultural, Environmental and Biological Sciences of the Federal University of Recôncavo da Bahia (UFRB), in the city of Cruz das Almas-BA.

The geographical coordinates of the city are latitude $12^{\circ} 40^{\prime} 12^{\prime \prime}$ South and longitude $39^{\circ} 06^{\prime} 07^{\prime \prime}$ West, with an altitude of $226 \mathrm{~m}$. According to the Köppen classification, the climate of the region is characterized as hot and humid (Am and Aw), with an annual average rainfall of 1,224 $\mathrm{mm}$, average annual temperature of $24^{\circ} \mathrm{C}$, and relative humidity of $80 \%$. The soil of the experimental area presents a flat relief, being classified as typical yellow distrocoses Latossolo, of medium texture and well-drained and deep (RODRIGUES et al., 2009).

Figure 1 presents the values of rainfall, relative humidity, and average temperature for each 10-day for the years 2013, 2014, and 2015. Table 1 shows the chemical attributes of the soil of the experimental area in the $0-0.20 \mathrm{~m}$ layer of depth. 


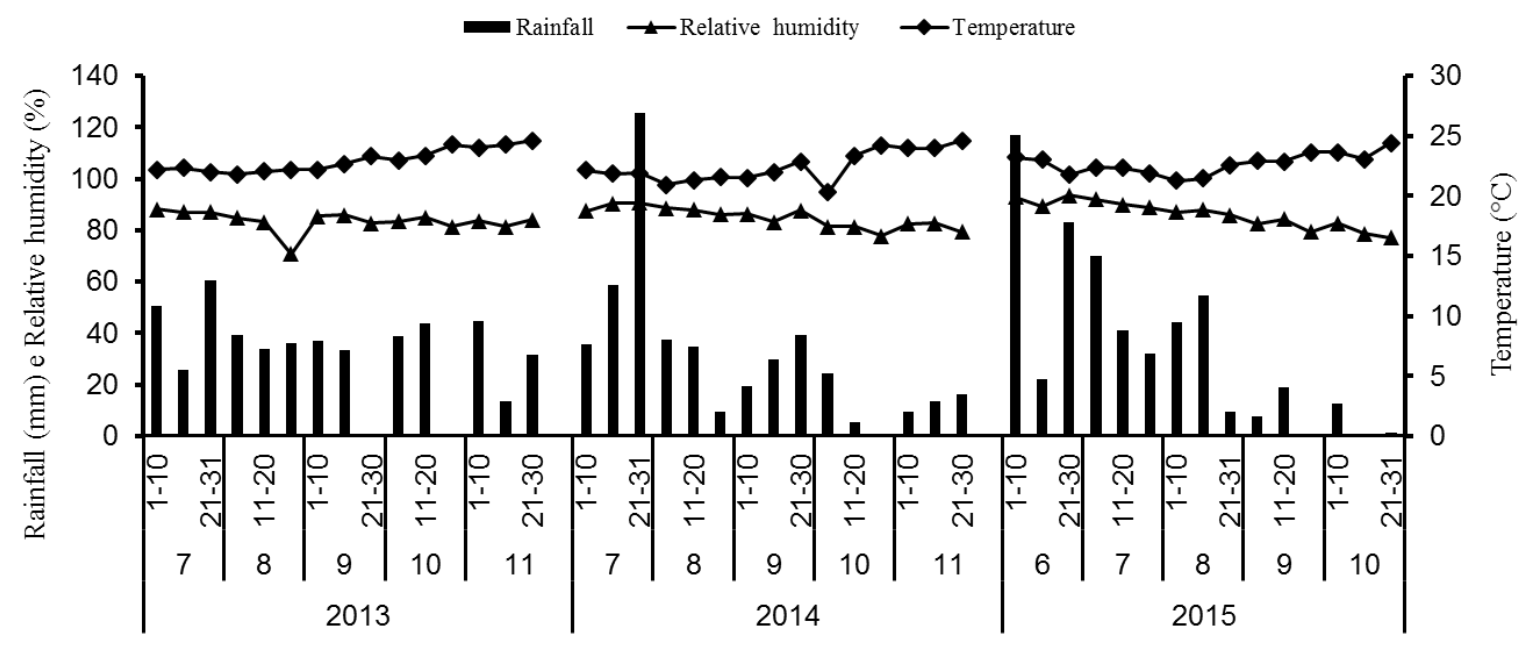

Source: CPTEC/INPE

Months year

Figure 1. Rainfall $(\mathrm{mm})$, relative air humidity $(\%)$, and mean air temperature $\left({ }^{\circ} \mathrm{C}\right)$ from July to November in the years of 2013 and 2014, and from June to October in the year 2015.

Table 1. Chemical soil attributes of the experimental area in the $0-0.20 \mathrm{~m}$ layer, in the three years of cultivation (2013, 2014 and 2015).

\begin{tabular}{|c|c|c|c|c|c|c|c|c|c|c|c|}
\hline \multirow{2}{*}{ Year } & $\mathrm{pH}$ & $\mathrm{P}$ & $\mathrm{B}$ & $\mathrm{Ca}^{+2}$ & $\mathrm{Mg}^{+2}$ & $\mathrm{Al}^{+3}$ & $\mathrm{H}^{+}$ & $\mathrm{K}^{+}$ & CTC & $\mathrm{MO}$ & $\mathrm{V}$ \\
\hline & (water) & \multicolumn{2}{|c|}{$\mathrm{mg} \mathrm{dm}{ }^{-3}$} & \multicolumn{6}{|c|}{$\begin{array}{l}\text {-------------------cmol } \mathrm{dm}^{-3} \text {---------------- } \\
\end{array}$} & \multicolumn{2}{|c|}{$---\%$---- } \\
\hline 2013 & 6.00 & 6.12 & 0.1 & 0.93 & 0.53 & 0.12 & 1.52 & 0.11 & 3.21 & 0.75 & 48.44 \\
\hline 2014 & 5.16 & 10.2 & 0.25 & 1.1 & 0.39 & 0.12 & 2.08 & 0.08 & 3.77 & 0.8 & 41.48 \\
\hline 2015 & 4.70 & 35.0 & 0.47 & 2.5 & 1.06 & 0.10 & 1.83 & 0.26 & 5.75 & 1.6 & 67.31 \\
\hline
\end{tabular}

Source: Lagro (Laboratory Agronômico S/C Ltda).

The experimental design was randomized blocks, in a $3 \times 3+1$ factorial scheme. Three intercropping of sunflower with forage plants were studied (SB: sunflower + Urochloa ruziziensis; SP: sunflower + Panicum maximum cv. Tanzania; and SBGu: sunflower + Urochloa ruziziensis + Cajanus cajan), in three forms in sowing (SS: simultaneous sowing of the intercropped, DS: delayed sowing of the intercropped, at 25 days after sowing of the sunflower, and $\mathrm{SSH}$ : simultaneous sowing of the intercropped with application of herbicide/graminicide), with additional treatment serving as a control (MS: monocropped sunflower), with four replicates, totaling 40 plots in three years of cultivation (2013, 2014 and 2015).

The experimental area was grooved, with rows spaced at $0.70 \mathrm{~m}$, and base fertilization was distributed within the grooves in the amounts of $276 \mathrm{~kg} \mathrm{ha}^{-1}$ (2013), $207 \mathrm{~kg} \mathrm{ha}^{-1}$ (2014), and $138 \mathrm{~kg}$ $\mathrm{ha}^{-1}$ (2015) of Top-Phos $280 \mathrm{HP}$ fertilizer $(\mathrm{N}=1 \%$, $\mathrm{P}_{2} \mathrm{O}_{5}=28 \%, \quad \mathrm{Ca}=17 \%, \mathrm{~S}=5 \%$ ). Additional fertilizer was applied manually at 25 days after emergence (DAE) of sunflower with $322 \mathrm{~kg} \mathrm{ha}^{-1}$, in each of the three years of cultivation, and consisted of Sulfammo Meta 11 fertilizer mixture
$\left(\mathrm{N}=15 \%, \mathrm{P}_{2} \mathrm{O}_{5}=3 \%, \mathrm{~K}=16 \%, \mathrm{~S}=4 \%, \mathrm{Ca}=4 \%, \mathrm{Cu}=\right.$ $0.1 \%, \mathrm{Mn}=0.2, \mathrm{Zn}=0.3 \%, \mathrm{~B}=0.2 \%$ ) and boric acid application $(17 \% \mathrm{~B})$ in amounts of $6 \mathrm{~kg} \mathrm{ha}^{-1}$ (2013) and $3 \mathrm{~kg} \mathrm{ha}^{-1}$ (2014 and 2015).

The experimental plot consisted of eight rows of $6.0 \mathrm{~m}$ in length, keeping the spacing between the rows of sunflower of fixed at $0.70 \mathrm{~m}$. Of these eight sowing lines, two (2nd and 3rd) were used for growth analysis (destructive samples of plants) and three (5th, 6th, and 7th) for evaluation of the agronomic characteristics and determination of the production components and the productivity of achenes, representing the useful portion. The two external lines (1st and 8th) and one of the central ones (4th) were considered as borders.

The sowing was carried out on July 17, 2013, July 18, 2014, and May 15, 2015. During the sowing, the Urochloa decumbens grass was desiccated, which served as a straw for sowing in the no-tillage system (NTS). The sowing of the sunflower hybrid (Olissum 3) was carried out with the help of a manual planter type ratchet, obeying the spacing of $0.70 \mathrm{~m}$ between sowing lines and $0.30 \mathrm{~m}$ between plants, with a fixed population of $47,000 \mathrm{ha}^{-1}$ plants (CASTRO et al., 1996; BRIGHENTI et al., 2008). The matracas were regulated to deposit three seeds to 
the soil. At 12 days after sowing (DAS), the sunflower was thinned, leaving only one plant.

The intercropped forage plants were sown manually, with sowing in furrows between the lines of the sunflower. In the treatment that comprised both forages (grass and legume), two sowing grooves were made in the sunflower interweave. The number of seeds used each year was calculated according to the cultural value $(\mathrm{CV})$ for the grasses (FERREIRA et al., 2007) and the percentage of germination associated with the recommendation for the culture in the case of the legume. All cultural treatments related to pest, disease, and weed management applied to the experimental plots (sunflower cultivation and intercropping forage plants) were performed according to technical recommendations and monitoring of incidence and level of control. A herbicide/graminicide spraying with the active ingredient fluazifop-p-butyl $\left(10 \mathrm{~g}\right.$ a.i. ha $\left.^{-1}\right)$ was used as sowing with herbicide application when grasses had three to four tillers. The syrup $\left(150 \mathrm{~L} \mathrm{ha}^{-1}\right)$ was applied from 06:00 to 08:00 in the morning, using a costal pump with directed jet and pre-calibrated fan nozzle.

At 111 days after sowing (DAS) in 2013, at 109 DAS in 2014, and at 113 DAS in 2015 , in the lines destined to the study of the agronomic and productive characteristics, which constituted the useful area, we randomly selected 10 plants from which we made measurements of plant height $(\mathrm{PH})$, (measured of the lap of the plant until the insertion of the chapter with the aid of a metric scale, stalk diameter (SD) (measured in the lap of the plant using a pachymeter), and head diameter (HD) (an imaginary line is drawn in the center of the chapter with the help of a tape measure). In the useful area, the productivity of achenes (PA), harvest index (HI), and mass production components of a thousand achenes (M1000) and the number of achenes per head (NAH) were evaluated, taking into account all plants of the working area, excluding $0.60 \mathrm{~m}$ of border at the ends of the lines. The NAH was obtained using the following formula: $\mathrm{NAH}=$ $[\mathrm{M} \times 1000 / \mathrm{M} 1000 \times \mathrm{C}]$, where: $\mathrm{NAH}=$ number of achenes per head, $\mathrm{M}=$ mass of achenes in the useful area $(\mathrm{g}), \mathrm{M} 1000=$ mass of 1000 achenes, and $\mathrm{C}=$ number of chapters in the useful area. This formula was used by Santos et al. (2016) in the study of sunflower productivity. The M1000 was determined according to the rules established by the Seed Analysis Rules (BRASIL, 2009), where eight subsamples of 100 achenes were separated by treatment, whose masses were determined in a scale $(0.001 \mathrm{~g})$, estimating the M1000.

To determine the productivity of achenes, all chapters of the useful area were collected manually, excluding $0.60 \mathrm{~m}$ of the border at the ends of the lines, which went through a process of threshing and processing by specific machinery. The achenes were weighed on a precision scale $(0.001 \mathrm{~g})$, recording the yield in $\mathrm{kg} \mathrm{plot}^{-1}$, and later estimated in $\mathrm{kg} \mathrm{ha}^{-1}$, after correction of the humidity to $11 \%$. The harvest index was determined by the ratio between the mass of the accumulated total dry matter or biological productivity (BP) and the economic production (EP), at full maturity (R9) at harvest, in this case, the dry mass of the achenes. After the final harvest of the sunflower plants, the experimental area was fallowed and used the following year to install a new experiment.

The data were submitted to the analysis of combined variance with the application of the F test. When a significant effect was found, the means of the treatments were compared by the Tukey test $(\mathrm{p} \leq 0.05)$ and the Dunnett test $(\mathrm{p} \leq 0.05)$ using the SAS statistical program (SAS, 2000).

\section{RESULTS AND DISCUSSION}

As can be observed in the analysis of combined variance (Table 2), there were no significant differences between treatments for plant height $(\mathrm{PH})$, stalk diameter $(\mathrm{SH})$, and head diameter (HC). The year factor showed significant differences, which was predictable given that rainfall directly influences the performance of the crop. Also, the yearly improvement in soil chemical characteristics also influenced these results. 
Table 2. Summary of the combined variance analysis for plant height (PH), stalk diameter (SD), head diameter (HD), number of achenes per head (NAH), mass of thousand achenes (M1000), productivity of achenes (PA), and harvest index (HI) of sunflower submitted to different intercropped and sowing forms, in the crop-livestock integration system, during three years of cultivation $(2013,2014$ and 2015).

\begin{tabular}{|c|c|c|c|c|c|c|c|c|}
\hline \multirow{2}{*}{ Source of variation } & \multirow[b]{2}{*}{ DF } & \multicolumn{7}{|c|}{ MS } \\
\hline & & $\mathrm{PH}$ & SD & HD & NAH & M1000 & PA & HI \\
\hline Blok (Year) & 9 & $687.189 * *$ & $0.10 * *$ & $5.77 * *$ & $1563209.51^{\mathrm{ns}}$ & $6.78^{\mathrm{ns}}$ & $17498.88^{\mathrm{ns}}$ & $0.01^{\mathrm{ns}}$ \\
\hline $\mathrm{SF}$ & 2 & $210.79^{\mathrm{ns}}$ & $0.21^{\mathrm{ns}}$ & $5.88^{\mathrm{ns}}$ & $1139414.38^{\mathrm{ns}}$ & $0.22^{\mathrm{ns}}$ & $132075.24 *$ & $0.13^{* *}$ \\
\hline Int & 2 & $48.04^{\mathrm{ns}}$ & $0.02^{\mathrm{ns}}$ & $1.44^{\mathrm{ns}}$ & $2461789.24^{\mathrm{ns}}$ & $5.80^{\mathrm{ns}}$ & $5429944.9^{* *}$ & $0.07 * *$ \\
\hline SF x Int & 4 & $49.04^{\mathrm{ns}}$ & $0.06^{\mathrm{ns}}$ & $2.33^{\mathrm{ns}}$ & $3075507.34^{\mathrm{ns}}$ & $15.50^{\mathrm{ns}}$ & $141974.08^{*}$ & $0.009^{\mathrm{ns}}$ \\
\hline Treat vs. Wit & 1 & $471.65^{*}$ & $0.07^{\mathrm{ns}}$ & $9.51^{*}$ & $848726.10^{\text {ns }}$ & $42.11^{*}$ & $456336.35^{* *}$ & $0.0001^{\mathrm{ns}}$ \\
\hline Year & 2 & $50294.07 * *$ & $10.60^{* *}$ & $258.89 * *$ & $25579556.3^{* *}$ & $1561.65^{* *}$ & $4707176.5^{* *}$ & $0.002^{\mathrm{ns}}$ \\
\hline SF x Year & 4 & $188.57^{\mathrm{ns}}$ & $0.04^{\mathrm{ns}}$ & $4.40^{\mathrm{ns}}$ & $1251038.37^{\mathrm{ns}}$ & $21.16^{*}$ & $178350.88^{* *}$ & $0.01^{\mathrm{ns}}$ \\
\hline Int $x$ Year & 4 & $75.99^{\text {ns }}$ & $0.05^{\mathrm{ns}}$ & $0.92^{\mathrm{ns}}$ & $558379.22 *$ & $43.25^{* *}$ & $1202640.82 * *$ & $0.017 *$ \\
\hline SF $x$ Int $x$ Year & 8 & $182.91^{\mathrm{ns}}$ & $0.02^{\mathrm{ns}}$ & $1.72^{\mathrm{ns}}$ & $3463869.91^{\mathrm{ns}}$ & $25.26^{* *}$ & $222359.27^{* *}$ & $0.03 * *$ \\
\hline Error & 81 & 121.16 & 0.035 & 2.31 & 2210102.6 & 9.67 & 40446.06 & 0.006 \\
\hline Mean & & 147.05 & 1.90 & 18.08 & 2200 & 39.03 & 2066 & 0.42 \\
\hline CV (\%) & & 7.48 & 9.95 & 8.42 & 67.56 & 7.96 & 9.73 & 18.62 \\
\hline
\end{tabular}

$* *=$ significant at $1 \%$ probability by $\mathrm{F}$ test; $*=$ significant at $5 \%$ probability by the $\mathrm{F}$ test; $\mathrm{ns}=$ not significant; $\mathrm{SF}=$ sowing form; Int $=$ intercropping; Treat $=$ treatments; $\mathrm{Wit}=$ witness; $\mathrm{CV}=$ coefficient of variation; $\mathrm{DF}=$ degrees of freedom; $\mathrm{MS}=$ mean square.

For the number of achenes per head (NAH), the analysis of combined variance revealed significant effects for the year $\times$ intercropped interaction (Table 2). As shown in Table 3 in the agricultural year 2014, the sunflower presented higher $\mathrm{NAH}$ for the three intercroppeds
( $\mathrm{SB}, \mathrm{SP}$, and $\mathrm{SBGu}$ ). In the evaluation within each agricultural year, it was possible to verify that there was no variation of the intercropped in 2014 and 2015, while in 2013, the intercropped SB influenced the plants to present higher NAH.

Table 3. Mean values in the significant interaction split Year $\times$ Intercropping for number of achenes per head $(\mathrm{NAH})$ observed in sunflower plants submitted to different intercropping (SB: sunflower + Urochloa ruziziensis; SP: sunflower + Panicum maximum cv. tanzânia SBGu: sunflower + Urochloa ruziziensis + Cajanus cajan), during three years of cultivation $(2013,2014$, and 2015).

\begin{tabular}{cccc}
\hline \multirow{2}{*}{ Year } & \multicolumn{3}{c}{ Intercropped } \\
\cline { 2 - 4 } & SB & SP & SBGu \\
\hline 2013 & $2213.33 \mathrm{bA}$ & $1698.55 \mathrm{bAB}$ & $1425.43 \mathrm{bB}$ \\
2014 & $3024.01 \mathrm{aA}$ & $2810.66 \mathrm{aA}$ & $3277.09 \mathrm{aA}$ \\
2015 & $1582.64 \mathrm{cA}$ & $1332.69 \mathrm{bA}$ & $1463.66 \mathrm{bA}$ \\
\hline
\end{tabular}

Means followed by the same lowercase letter in the column and upper case in the row do not differ statistically from each other by the Tukey test at $5 \%$ probability.

This significant increase in the number of achenes in the year 2014 relative to the other years might be related to the lower water availability in the flowering period (60 DAE) and the formation of achenes (75 to 90 DAE) (Table 3). Figure 1 shows that there was little precipitation in 2014, and the occurrence of water restrictions in the period of development of achenes affects plant physiology (mainly production components and productivity). The insufficient water availability for the sunflower plant can differentially affect the yield parameters of the crop, such as the NAH. This restriction has influenced the plants to produce a greater number of achenes, with a smaller mass and/or the presence of light achenes or no content, which reflected in lower yields of achenes in 2014 (Tables 3, 5, and 7). 
Table 4. Differences between averages for the number of achenes per head (NAH) observed in the monocropped sunflower plants and those submitted to the intercroppeds in different sowing forms in the crop years 2013, 2014, and 2015.

\begin{tabular}{lccc}
\hline Contrast (Treat vs. Wit) & \multicolumn{3}{c}{ NAH } \\
\hline & 2013 & 2014 & 2015 \\
\cline { 2 - 4 } SB.SS - MS & -8.0 & 271.0 & $780.53^{*}$ \\
SP.SS - MS & 274.0 & -320.8 & $402.43^{*}$ \\
SBGu.SS - MS & -570.0 & 720.9 & $430.34^{*}$ \\
SB.DS - MS & 1046.0 & -112.7 & 234.23 \\
SP.DS - MS & -142.0 & 69.60 & 252.63 \\
SBGu.DS - MS & -451.0 & 228.0 & 138.83 \\
SB.SSH - MS & -18.0 & 720.90 & $443.16^{*}$ \\
SP.SSH - MS & -657.0 & 60.80 & 53.01 \\
SBGu.SSH - MS & 3359.0 & 260.0 & $531.81^{*}$ \\
\hline
\end{tabular}

*Significant at $5 \%$ probability by Dunnett's t-test. MS: monocropped sunflower; SB: sunflower + Urochloa ruziziensis; SP: sunflower + Panicum maximum cv. Tanzania; SBGu: sunflower + Urochloa ruziziensis + Cajanus cajan; SS: simultaneous sowing; DS: delayed sowing; SSH: simultaneous sowing with herbicide application.

Table 4 shows that, in 2013, for the majority of the comparison (although not statistically different), the sunflower in a intercropped presented lower a NAH. As early as 2014, the inverse occurred, since the sunflower intercropped mostly produced higher NAHs. However, in contrast, the comparisons showed significant differences between the intercropped in relation to the single crop, and the intercropped of SS and SSH were superior to DS, and it can be inferred that in that year the presence of the intercropped plants and the sowing form influenced the sunflower plant to produce a greater amount of achenes, associated with a higher rainfall distribution in this year when compared to the others. Souza et al. (2015), evaluating the intercropped sunflower of Brachiaria ruziziensis, also verified an increase in NAH when grown in an intercropped in relation to single crop.

Table 5. Mean values of the mass of thousand achenes (M1000) in grams, observed in sunflower plants submitted to different intercropping (SB: sunflower + Urochloa ruziziensis; SP: sunflower + Panicum maximum cv Tanzania and SBGu: sunflower + Urochloa ruziziensis + Cajanus cajan) and sowing forms (SS: simultaneous sowing, DS: delayed sowing and SSH: simultaneous sowing with herbicide/graminicide application) during three years of cultivation (2013, 2014 and 2015).

\begin{tabular}{|c|c|c|c|}
\hline \multirow{3}{*}{ Forms of sowing } & \multicolumn{3}{|c|}{ Intercropped } \\
\hline & \multicolumn{3}{|c|}{ Year 2013} \\
\hline & SB & SP & SBGu \\
\hline Simultaneous (SS) & $36.76 \mathrm{aA}$ & $39.00 \mathrm{aA}$ & $37.32 \mathrm{aA}$ \\
\hline Delayed (SD) & $34.92 \mathrm{aA}$ & $37.70 \mathrm{aA}$ & $37.14 \mathrm{aA}$ \\
\hline \multirow[t]{3}{*}{ Simultaneous with herbicide ( $\mathrm{SSH}$ ) } & $38.60 \mathrm{aA}$ & $38.25 \mathrm{aA}$ & $37.82 \mathrm{aA}$ \\
\hline & \multicolumn{3}{|c|}{ Year 2014} \\
\hline & SB & SP & SBGu \\
\hline Simultaneous (SS) & $33.42 \mathrm{aA}$ & $35.45 \mathrm{aA}$ & $33.93 \mathrm{aA}$ \\
\hline Delayed (SD) & $31.74 \mathrm{aA}$ & $34.28 \mathrm{aA}$ & $33.76 \mathrm{aA}$ \\
\hline \multirow[t]{3}{*}{ Simultaneous with herbicide (SSH) } & $35.09 \mathrm{aA}$ & $34.77 \mathrm{aA}$ & $34.38 \mathrm{aA}$ \\
\hline & \multicolumn{3}{|c|}{ Year 2015} \\
\hline & SB & SP & SBGu \\
\hline Simultaneous (SS) & $49.78 \mathrm{aA}$ & $39.89 \mathrm{aB}$ & $48.33 \mathrm{aA}$ \\
\hline Delayed (SD) & $50.67 \mathrm{aA}$ & $44.75 \mathrm{aA}$ & $47.55 \mathrm{aA}$ \\
\hline Simultaneous with herbicide (SSH) & $46.27 \mathrm{aA}$ & $47.01 \mathrm{aA}$ & $40.65 \mathrm{aA}$ \\
\hline
\end{tabular}

Means followed by the same lowercase letter in the column and upper case in the row do not differ statistically from each other by the Tukey test at $5 \%$ probability. 
For the M1000 characteristic, there were statistical differences with a triple interaction of the sources of variation (Table 2). In comparison with the studied factors, difference observed for the sunflower cultivated in the SP intercropped in simultaneous sowing in the year 2015 (Table 5). Simultaneous sowing of the Panicum maximum cv.
Tanzania promoted greater competition with sunflower, as this grassland presents rapid establishment and vigorous growth. When comparing the single crop with the sunflower intercropped, it is possible to verify that the intercropped plants presented higher M1000 (Table 6).

Table 6. Differences between averages for the mass of one thousand achenes (M1000) observed in for monocropped sunflower plants and submitted to the intercropping in different sowing forms during three years of cultivation (2013, 2014, and 2015).

\begin{tabular}{lccc}
\hline Contrast (Treat vs. Wit) & \multicolumn{3}{c}{ M1000 (g) } \\
\hline & 2013 & 2014 & 2015 \\
\cline { 2 - 4 } SB.SS - MS & 0.293 & 2.539 & 5.354 \\
SP.SS - MS & 2.532 & $4.575^{*}$ & -4.53 \\
SBGu.SS - MS & 0.856 & 3.051 & 3.911 \\
SB.DS - MS & -1.548 & 0.865 & 6.251 \\
SP.DS - MS & 1.239 & 3.399 & 0.324 \\
SBGu.DS - MS & 0.673 & 2.885 & 3.128 \\
SB.SSH - MS & 2.132 & 4.211 & 1.850 \\
SP.SSH - MS & 1.780 & 3.891 & 2.581 \\
SBGu.SSH - MS & 1.350 & 3.500 & -3.77 \\
\hline
\end{tabular}

*Significant at $5 \%$ probability by Dunnett's t-test. MS: monocropped sunflower; SB: sunflower + Urochloa ruziziensis; SP: sunflower + Panicum maximum cv. Tanzania; SBGu: sunflower + Urochloa ruziziensis + Cajanus cajan; SS: simultaneous sowing; DS: delayed sowing; SSH: simultaneous sowing with herbicide application.

For the characteristic productivity, there was a significant interaction for all factors studied (Table 2).

The evaluation of the yield of achenes of sunflower intercropped in the agricultural year of 2013 indicated that the forage Panicum maximum cv. Tanzania caused interference in this characteristic, so that when the sunflower was cultivated in the other intercropped (SB and SBGu), it presented higher productivities, reaching a maximum of $3011.67 \mathrm{~kg}$ $\mathrm{ha}^{-1}$ in the intercropped SBGu with herbicide/ graminicide application (Table 7). This higher productivity, despite being obtained in a triple intercropped, probably occurred due to the application of the herbicide/graminicide, which limits the growth of the grass. Also, the presence of the legume might have contributed to the increase of productivity, thereby promoting the improvement of soil characteristics, or even to the simultaneous addition of nitrogen to the soil. It is also observed that in the year 2013, in addition to the SBGu intercropped, SB presented high productivity, regardless of the sowing form.

In the study of the competition of forages with a corn crop, Jakelaitis et al. (2005) observed that the application of post-emergent herbicide influences the greater development and productivity of the grain culture. In this research, the application of the herbicide, in the year of 2013, promoted greater productivity of the crop. 
Table 7. Mean values of productivity of achenes, in $\mathrm{kg} \mathrm{ha}^{-1}$, observed for sunflower plants submitted to different intercropping (SB: sunflower + Urochloa ruziziensis; SP: sunflower + Panicum maximum cv Tanzania and SBGu: sunflower + Urochloa ruziziensis + Cajanus cajan) and sowing form (SS: simultaneous sowing, SD: delayed sowing and SSH: simultaneous sowing with herbicide/graminicide application) during 3 years of cultivation $(2013,2014$, and 2015).

\begin{tabular}{lccc}
\hline & \multicolumn{3}{c}{ Intercropped } \\
\cline { 2 - 4 } Forms of sowing & SB & Sear 2013 & SBGu \\
\cline { 2 - 4 } & $2522.69 \mathrm{aA}$ & $1487.18 \mathrm{aB}$ & $2104.20 \mathrm{bA}$ \\
\hline Simultaneous (SS) & $2446.50 \mathrm{aA}$ & $1645.96 \mathrm{aB}$ & $2042.25 \mathrm{bAB}$ \\
Delayed (DS) & $2468.22 \mathrm{aB}$ & $1595.50 \mathrm{aC}$ & $3011.67 \mathrm{aA}$ \\
Simultaneous with herbicide (SSH) & \multicolumn{3}{c}{ Year 2014} \\
\hline & SB & SP & SBGu \\
\cline { 2 - 4 } & $1701.00 \mathrm{aB}$ & $1560.88 \mathrm{bC}$ & $1870.79 \mathrm{aA}$ \\
Simultaneous (SS) & $1665.80 \mathrm{aA}$ & $1744.79 \mathrm{aA}$ & $1718.59 \mathrm{bA}$ \\
Delayed (DS) & $1786.08 \mathrm{aA}$ & $1769.83 \mathrm{aA}$ & $1774.92 \mathrm{abA}$ \\
Simultaneous with herbicide (SSH) & \multicolumn{3}{c}{ Year 2015} \\
\hline
\end{tabular}

Means followed by the same lowercase letter in the column and upper case in the row do not differ statistically from each other by the Tukey test at $5 \%$ probability.

In 2014 (Table 7) in the SBGu intercropping with simultaneous sowing, the sunflower was more productive, reaching $1870.79 \mathrm{~kg} \mathrm{ha}^{-1}$, unlike the SP intercropped, which presented lower productivity $\left(1560.88 \mathrm{~kg} \mathrm{ha}^{-1}\right)$. According to Tiritan et al. (2013), the use of legumes in a intercropped system enhances the performance of the other intercropped plants.

Tanzania grass (Panicum maximum) (SP) negatively influenced the sunflower productivity, under any form of sowing, in the years 2013 and 2015, compared to SB and SBGu, since the growth of this forage is more aggressive, causing interspecific competition. On the other hand, in 2015 , the SB intercropped was the one that presented the highest productivity in delayed sowing (3021.54 $\mathrm{kg} \mathrm{ha}^{-1}$ ), with less interference of forage competition in the sunflower (Table 7).

In the comparison of years, sunflower yields in 2014 were lower than the other growing periods. This is because of climatic conditions during the study period (Figure 1). Water scarcity in critical periods (flowering and filling of achenes), in which the plant requires a greater amount of water, influenced its development, which was reflected in lower yields. We also observed a beneficial effect of the SB and SBGu intercropped on the different sowing forms in the agricultural years 2013 and 2015 , in which rainfall occurred more regularly (Table 7).

As can be seen in the comparative contrasts between the sunflower grown in a intercropped system in the different sowing forms and the monocropped sunflower (Table 8), the Tanzanian grass forage (Panicum maximum) affects the productivity of the sunflower even in late plantings of these plants. This characteristic of aggressiveness of this forage on the sunflower can be related to its habit of growth and tillering with the formation of clumps. In addition, in competition for light, grass (C4 photosynthetic metabolism) was also more competitive because of the partially shading by the sunflower plants (C3 photosynthetic metabolism), with reduce the uptake of light radiation, which reflected the lower photosynthetic capacity of sunflower plants and, consequently, reduced productivity, regardless of the way of implantation of intercropped. 
Table 8. Differences between averages for productivity of achenes (PA) observed in monocropped sunflower plants and submitted to intercropping in different sowing forms in the growing years 2013, 2014, and 2015.

\begin{tabular}{lccc}
\hline Contrast (Treat vs. Wit) & \multicolumn{3}{c}{ PA $\left(\mathrm{kg} \mathrm{ha}^{-1}\right)$} \\
\hline & 2013 & 2014 & 2015 \\
\cline { 2 - 4 } SB.SS - MS & 254.1 & $429.2^{*}$ & $489.6^{*}$ \\
SP.SS - MS & $-781.4^{*}$ & $289.1^{*}$ & $-556.0^{*}$ \\
SBGu.SS - MS & -164.4 & $599.0^{*}$ & $814.3^{*}$ \\
SB.DS - MS & 178.0 & $394.0^{*}$ & $917.7^{*}$ \\
SP.DS - MS & $-622.6^{*}$ & $473.0^{*}$ & $-391.0^{*}$ \\
SBGu.DS - MS & -226.3 & $446.8^{*}$ & $563.6^{*}$ \\
SB.SSH - MS & 199.7 & $514.3^{*}$ & $625.0^{*}$ \\
SP.SSH - MS & $-673.0^{*}$ & $498.0^{*}$ & $-418.0^{*}$ \\
SBGu.SSH - MS & $743.1^{*}$ & $503.1^{*}$ & $452.0^{*}$ \\
\hline
\end{tabular}

*Significant at $5 \%$ probability by Dunnett's t-test. MS: monocropped sunflower; SB: sunflower + Urochloa ruziziensis; SP: sunflower + Panicum maximum cv. Tanzania; SBGu: sunflower + Urochloa ruziziensis + Cajanus cajan; SS: simultaneous sowing; DS: delayed sowing; SSH: simultaneous sowing with herbicide application.

In the intercropped involving Tanzania grass, the physiological indicators of competition are different when compared to the other forages because of the great competitive capacity of this grass. We found that, in the years of 2013 and 2015, the contrasts of the SP vs. MS, whether in simultaneous sowing, delayed or with herbicide application, were significant and negative, indicating that MS presented higher yields than SP treatments. By 2014, the contrasts were positive, indicating that the sunflower produced more in intercropping than in single crops. Comparing the intercropped within each sowing form, the sunflower presented a reduction in productivity when intercropped with Panicum maximum (SP) (Table 7).

The harvest index (HI) is defined as the ratio between the total dry matter mass of the plant and the economic fraction produced (grain/seed, aquarium, pod, root, leaf, and fruit) (PEIXOTO; CRUZ; PEIXOTO, 2011). The use of the HI in studies of comparison between cultivars or systems of intercropped identifies the efficiency of the plant of interest in converting the phytomass produced into a marketable economic product that, in the case of sunflower, are the achenes or the chapter itself.

We detected variation in the results for each intercropped and sowing form. In the year 2013, the intercropped SB in SS and DS and the intercropped SBGu in DS and SSH presented higher HIs. By 2014, the SBGu intercropped in DS had a greater capacity to turn gross productivity into economic gain. For the year 2015, SB intercropped in DS and SBGu in SS and DS obtained higher values of HI (Table 9). 
Table 9. Mean values of harvest index (HI) observed in sunflower plants submitted to different intercropping (SB: sunflower + Urochloa ruziziensis; SP: sunflower + Panicum maximum cv. Tanzania and SBGu: sunflower + Urochloa ruziziensis + Cajanus cajan) and sowing form (SS: simultaneous sowing, DS: delayed sowing and SSH: simultaneous sowing with herbicide/graminicide application) during three years of cultivation $(2013,2014$, and 2015).

\begin{tabular}{|c|c|c|c|}
\hline \multirow{3}{*}{ Forms of sowing } & \multicolumn{3}{|c|}{ Intercropped } \\
\hline & \multicolumn{3}{|c|}{ Year 2013} \\
\hline & SB & SP & $\mathrm{SBGu}$ \\
\hline Simultaneous (SS) & $0.46 \mathrm{aA}$ & $0.41 \mathrm{aA}$ & $0.24 \mathrm{bB}$ \\
\hline Delayed (DS) & $0.53 \mathrm{aA}$ & $0.41 \mathrm{aA}$ & $0.49 \mathrm{aA}$ \\
\hline \multirow[t]{3}{*}{ simultaneous with herbicide (SSH) } & $0.46 \mathrm{aAB}$ & $0.33 \mathrm{aB}$ & $0.50 \mathrm{aA}$ \\
\hline & \multicolumn{3}{|c|}{ Year 2014} \\
\hline & SB & SP & $\mathrm{SBGu}$ \\
\hline Simultaneous (SS) & $0.41 \mathrm{aA}$ & $0.33 \mathrm{aA}$ & $0.39 \mathrm{bA}$ \\
\hline Delayed (DS) & $0.45 \mathrm{aB}$ & $0.42 \mathrm{aB}$ & $0.62 \mathrm{aA}$ \\
\hline \multirow[t]{3}{*}{ simultaneous with herbicide (SSH) } & $0.42 \mathrm{aA}$ & $0.33 \mathrm{aA}$ & $0.32 \mathrm{bA}$ \\
\hline & \multicolumn{3}{|c|}{ Year 2015} \\
\hline & SB & SP & SBGu \\
\hline Simultaneous (SS) & $0.32 \mathrm{bB}$ & $0.34 \mathrm{aB}$ & $0.53 \mathrm{aA}$ \\
\hline Delayed (DS) & $0.55 \mathrm{aA}$ & $0.41 \mathrm{aB}$ & $0.53 \mathrm{aA}$ \\
\hline Simultaneous with herbicide (SSH) & $0.37 \mathrm{bA}$ & $0.33 \mathrm{aA}$ & $0.40 \mathrm{bA}$ \\
\hline
\end{tabular}

Means followed by the same lowercase letter in the column and upper case in the row do not differ statistically from each other by the Tukey test at $5 \%$ probability.

We found that the SB and SBGu intercropped are more efficient relative to the SP for this characteristic, and it can be inferred that the palisadegrass is a grass that competes little with the sunflower crop and that the presence of the pigeon pea might have influenced the improvement of this index, while the intercropped with the tanzania grass influenced the HI, resulting in greater competitiveness with the sunflower, because it presents two peculiar characteristics of aggressiveness (rapid multiplication and intense vegetation of the vegetal material).

It is possible to observe that in the years of 2013 and 2014, the contrasts that presented the differences between the intercropped and the single cultivation for the HI were smaller compared to 2015 , in which the presence of the intercropped propelled the sunflower to present higher HI (Table 10). It is also noticeable that in 2013 , the interference of Tanzania grass in the intercropped with the sunflower in the three sowing forms was evident, presenting negative values of contrast, implying, in this way, a greater competition of this forage with the sunflower, mainly in delayed sowing. The differences between the means of the intercropped and the single crop in the three years of cultivation indicate that 2015 achieved one with the highest indexes, reaching a significant difference of 6,251 in the SB intercropped in DS. This is likely be related to the improvement of soil characteristics by the cumulative presence of straw over the years since the water regime was similar at the end of the cycle for the 3 consecutive years (Table 1, Figure 1). 
Table 10. Differences between averages for the harvest index (HI) observed in monocropped sunflower plants and submitted to intercropping in different sowing forms in the growing years of 2013, 2014, and 2015.

\begin{tabular}{lccc}
\hline Contrast (Treat vs. Wit) & \multicolumn{3}{c}{ HI } \\
\hline & 2013 & 2014 & 2015 \\
\cline { 2 - 4 } SB.SS - MS & 0.046 & 0.028 & 5.354 \\
SP.SS - MS & -0.003 & -0.054 & -4.531 \\
SBGu.SS - MS & $-0.170^{*}$ & 0.001 & $3.911^{*}$ \\
SB.DS - MS & 0.118 & 0.058 & $6.251^{*}$ \\
SP.DS - MS & -0.002 & 0.033 & 0.324 \\
SBGu.DS - MS & 0.082 & $0.237^{*}$ & $3.128^{*}$ \\
SB.SSH - MS & 0.050 & 0.031 & 1.850 \\
SP.SSH - MS & -0.083 & -0.055 & 2.581 \\
SBGu.SSH - MS & 0.087 & -0.070 & -3.770 \\
\hline
\end{tabular}

*Significant at $5 \%$ probability by Dunnett's t-test. MS: monocropped sunflower; SB: sunflower + Urochloa ruziziensis; SP: sunflower + Panicum maximum cv. Tanzania; SBGu: sunflower + Urochloa ruziziensis + Cajanus cajan; SS: simultaneous sowing; DS: delayed sowing; SSH: simultaneous sowing with herbicide application.

Based on our findings, it is possible to verify that-with the exception of Tanzania grass-the use of fodder plants was advantageous in the productive development of the sunflower crop, becoming important the management adequacy in the area of planting in order to minimize existing intra and interspecific competitions, with late sowing or the use of herbicide/graminicide underdose. Therefore, it can be inferred that the choice of the forage species and the season of a intercropped are the most important factors for the success of the intercropped approach when growing sunflower grains. Therefore, it is evident that some requirements are necessary to implement systems integrated with the sunflower crop and the importance of understanding the multiplicity of possible interactions between the various components of the system, such as the peculiarity of each species and the environment.

\section{CONCLUSIONS}

The CLI system increases the productive characteristics of sunflower relative to the monocropped for the sunflower + Urochloa ruziziensis (SB) and sunflower + Urochloa ruziziensis + Cajanus cajan $(\mathrm{SBGu})$ intercropped.

Tanzania grass fodder (Panicum maximum) competes, significantly reducing plant production components and sunflower productivity.

Simultaneous sowing with herbicide/ graminicide application and delayed sowing promote higher yields of sunflower.

\section{REFERENCES}

AMORIM, E. P. et al. Correlações e análise de trilha em girassol. Bragantia, v. 67, n. 2, p. 307-316, 2008.

BRASIL. Ministério da Agricultura e Abastecimento. Regras para análise de sementes. Brasília: Departamento Nacional de Produção Vegetal, 2009. 399 p. Disponível em: <http:// www.agricultura.gov.br/assuntos/insumosagropecuarios/arquivos-publicacoesinsumos/2946_regras_analise_sementes.pdf $>$. Acesso em: 25 jan. 2016.

BRIGHENTI, A. M. et al. Integração lavourapecuária: a cultura do girassol consorciado com Brachiaria ruziziensis. 1. ed. Juiz de Fora: EMBRAPA, 2008. 12 p. (Circular Técnica, 96).

CASTRO, C. et al. A cultura do girassol. 1. ed. Londrina, PR: EMBRAPA, 1996. 36 p. (Circular Técnica, 13).

CECCON, G. et al. Uso de herbicidas no consórcio milho safrinha com Brachiaria ruziziensis. Planta Daninha, v. 28, n. 2, p. 359-364, 2010.

COMPANHIA NACIONAL $\mathrm{DE}$ ABASTECIMENTO - CONAB. Acompanhamento da safra brasileira de grãos 2016/2017, sétimo levantamento - abril 2017. Disponível em: $<\mathrm{http}: / /$ www.conab.gov.br/conteudos.php?a $=1253>$. Acesso em: 03 mai. 2017. 
CRUSCIOL, C. A. C. et al. Integração lavourapecuária: benefício das gramíneas perenes nos sistemas de produção. Informações Agronômicas, s/v., n. 125, p. 2-15, 2009.

FERREIRA, L. R. et al. Formação de pastagens em sistemas de integração. Informe Agropecuário, v. 28, n. 240, p. 52-62, 2007.

GOMES, A. H. S.; CHAVES, L. H. G.; GUERRA, H. O. C. Drip Irrigated Sunflower Intercropping. American Journal of Plant Sciences, v. 6, n. 11, p. 1816-1821, 2015.

JAKELAITIS, A. et al. Influência de herbicidas e de sistemas de semeadura de Brachiaria brizantha consorciada com milho. Planta Daninha, v. 23, n. 1, p. 59-67, 2005.

LOSS, A. et al. Agregação, carbono e nitrogênio em agregados do solo sob plantio direto com integração lavoura-pecuária. Pesquisa Agropecuária Brasileira, v. 46, n. 10, p. 1269-1266, 2011.

NASCENTE, A. S.; LI, Y.; CRUSCIOL, C. A. C. Soil Aggregation, Organic Carbon Concentration, and Soil Bulk Density as Affected by Cover Crop Species in a No-Tillage System. Revista Brasileira de Ciência do Solo, v. 39, n. 3, p. 871-879, 2015.

OLIVEIRA, I. R. et al. Avaliação de cultivares de girassol em municípios dos Estados da Bahia, Alagoas, Sergipe e Rio Grande do Norte: ensaios realizados no ano agrícola de 2008. 1. ed. Aracajú: EMBRAPA, 2010. 6 p. (Circular técnica, 105).

OLIVEIRA, P. et al. Consórcio de milho com braquiária e guandu-anão em sistema de dessecação parcial. Pesquisa Agropecuária Brasileira, v. 46, n. 10, p. 1184-1192, 2011.

PARIZ, C. M. et al. Produtividade de grãos de milho e massa seca de braquiárias em consórcio no sistema de integração lavoura-pecuária. Ciência Rural, v. 41, n. 5, p. 875-882, 2011.

PEIXOTO, C. P.; CRUZ, T. V.; PEIXOTO, M. F. S. P. Análise do crescimento quantitativo de plantas: Conceitos e práticas. Enciclopedia Biosfera, v. 7, n. 13, p. 51-76, 2011.

RODRIGUES, M. da G. F. et al. Solos e suas relações com as paisagens naturais no município de Cruz das Almas - BA. Revista de Biologia e Ciências da Terra, v. 9, n. 2, p. 193-205, 2009.

RODRIGUES, C. F. et al. Sistema de consórcio do girassol, feijão-de-corda e amendoim em series de substituição. Revista Brasileira de Agricultura
Irrigada, v. 8, n. 3, p. 256-269, 2014.

SANTOS, C. A. C. et al. Produtividade do girassol sob a ação de bioestimulante vegetal em diferentes condições de semeadura no sistema plantio direto. Revista de Ciências Agroambientais, v. 14, n. 2, p. 83-91, 2016.

SAS Institute Inc. SAS/STAT. SAS User's Guide. 8.0. Cary, NC, 1, p. 2000.

SCHUNKE, R. M. Alternativas de manejo de pastagem para melhor aproveitamento do nitrogênio do solo. 1. ed. Campo Grande: EMBRAPA, 2001. 26 p. (Documentos, 111).

SILVA, A. C. et al. Consórcio entre feijão e Brachiaria brizantha sob doses reduzidas de graminicida. Planta Daninha, v. 24, n. 1, p. 71-76, 2006.

SOUZA, F. R. et al. Características agronômicas do cultivo de girassol consorciado com Brachiaria ruziziensis. Revista Ciência Agronômica, v. 46, n. 1, p. 110-116, 2015.

SHEAHAN, C. M. Plant guide for pigeonpea (Cajanus cajan). 1. ed. USA:USDA/NRCS, 2012. 4 p.

TIRITAN, C. S. et al. Bromatological composition of sorghum, millet plant and midgetguandu at different cut times in intercropping and monoculture. Acta Scientiarum. Agronomy, v. 35, n. 2, p. 183190, 2013. 